\title{
RADIOCARBON IN ANNUAL CORAL RINGS OF BELIZE AND FLORIDA
}

\section{ELLEN M DRUFFEL}

Mount Soledad Radiocarbon Laboratory, Department of Chemistry, University of California, San Diego, La Jolla, California 92093

ABSTRACT. Radiocarbon measurements on a 109-year-old (1868-1977) core of Montastrea annularis coral from Glover Reef, Belize, in the Gulf of Honduras, reveal uptake of fossil fuel $\mathrm{CO}_{2}$ and bomb ${ }^{14} \mathrm{C}$ by surface ocean waters. The history of $\Delta^{14} \mathrm{C}$ values revealed by this Belize growth agree remarkably well with results for coral growth from the Florida Straits. It is concluded that these corals are reliable recorders of ${ }^{14} \mathrm{C}$ concentrations of dissolved inorganic carbon (DIOG) in surface waters representative of the Gulf Stream.

\section{INTRODUCTION}

Radiocarbon measurements of dissolved inorganic carbon (DIOC) in sea water have been used in the past to reveal many aspects of circulation patterns for the world's oceans. Low $\Delta^{14} \mathrm{C}$ values obtained for equatorial and polar surface waters reveal varying degrees of upwelling for these areas (Rafter, 1968; Linick, 1975). Higher ${ }^{14} \mathrm{C}$ levels in mid-gyre areas of the Atlantic and Pacific Oceans illustrate considerably less communication with deeper waters than do upwelling regions (Broecker and others, 1960; Östlund, Dorsey, and Rooth, 1974; Bien, Rakestraw, and Suess, 1960). Bomb ${ }^{14} \mathrm{C}$ concentrations in equatorial surface waters have been used to estimate upwelling rates and $\mathrm{CO}_{2}$ exchange rates between the atmosphere and ocean (Broecker, Peng, and Stuiver, 1978).

Recently, Druffel and Linick (1978) reported $\Delta^{14} \mathrm{C}$ values found for a 175-year-old (AD 1800-1974) core of Montastrea annularis coral that grew off the Florida Keys $\left(24^{\circ} 57^{\prime} \mathrm{N}, 83^{\circ} 30^{\prime} \mathrm{W}\right)$. Pre-anthropogenic $\Delta^{14} \mathrm{C}$ values in the coral were constant throughout the entire 19th century at $-51 \%$. The input of dead $\mathrm{CO}_{2}$ to the atmosphere by the burning of fossil fuels since the turn of this century decreased the $\Delta^{14} \mathrm{C}$ in these surface waters to $-62 \%$ by 1954 . The uptake of bomb ${ }^{14} \mathrm{C}$ by these Gulf Stream waters increased $\Delta^{14} \mathrm{C}$ values to $215 \%$ above normal by 1970 , similar to those increases seen for North Atlantic surface waters (Östlund, Dorsey, and Rooth, 1974; Östlund, Dorsey, and Brescher, 1976).

\section{The coral samples}

Hermatypic (reef-building) coral accrete calcium carbonate in the form of aragonite whose main carbon source is DIOC from sea water. Weber (1974) showed that $\delta^{13} \mathrm{C}$ values for hermatypic coral skeletons are close to those for the DIOC of the surrounding ocean waters and that metabolic $\mathrm{CO}_{2}$ from the coral polyps is the only other minor source of carbon to the skeleton. This is of no consequence, however, because zooplankton, whose $\Delta^{14} \mathrm{C}$ is virtually the same as that for DIOC in sea water, is the main constituent in the coral's diet (Williams and Linick, 1975; Linick, 1978). Aragonite does not exchange its $\mathrm{CO}_{2}$ with other carbonates, nor does it dissolve to any significant degree. Thus, once accreted, aragonitic bands remain a permanent record of past radiocarbon levels. 

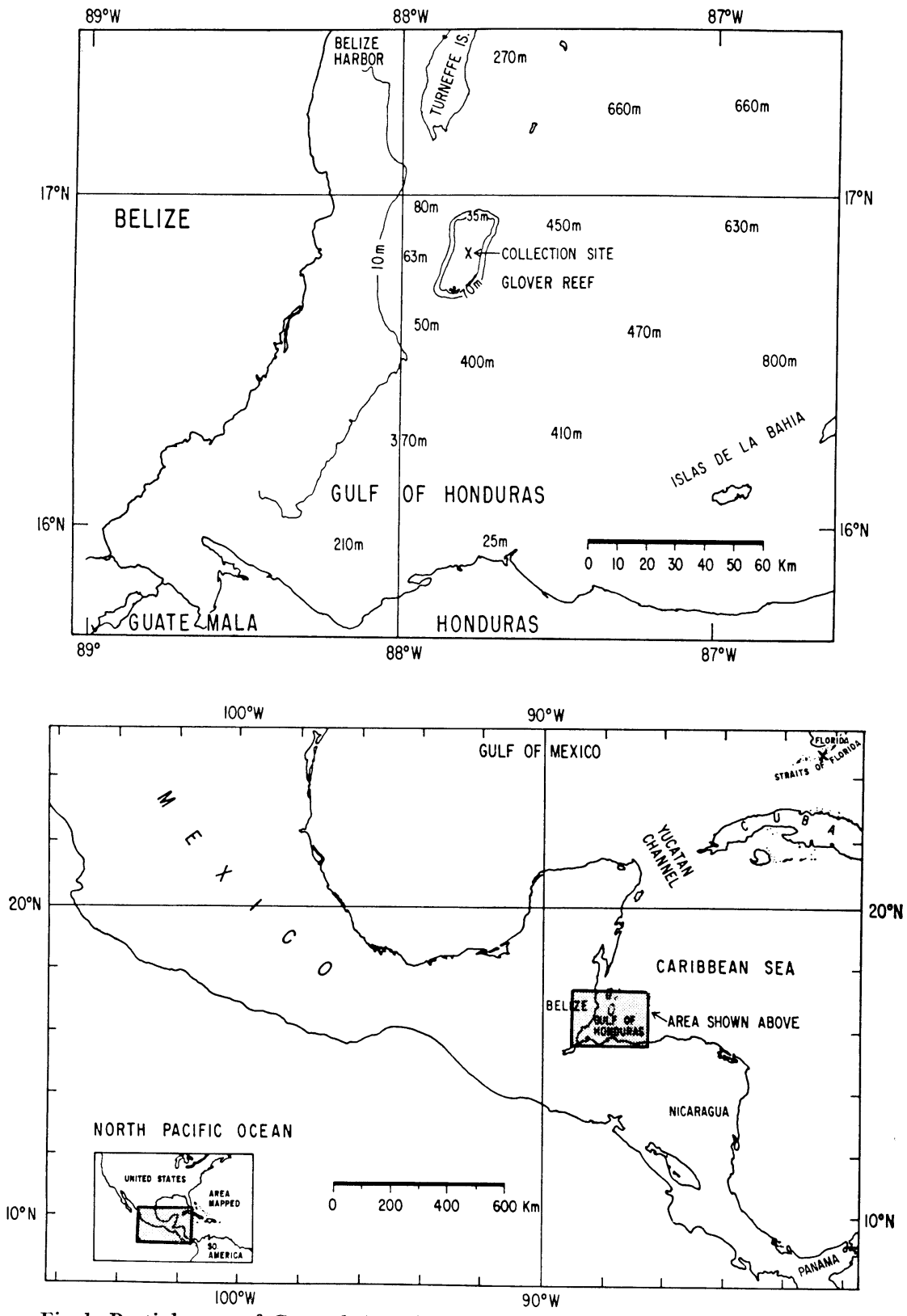

Fig 1. Partial map of Central America. The Florida collection site is indicated by an $X$ in the upper right-hand corner of this map. Upper portion shows Belize and the coral collection site from Glover Reef. 
Most reef-building corals growing in the world's oceans exhibit annual growth bands in their accreted aragonite. The bands are primary skeletal characteristics, that form as seasonal variations in the bulk density of the aragonitic material. Field observations, alizarin-staining techniques, autoradiography, and stable isotope measurements have been employed to establish the annual periodicity of these density bands (Knutson, Buddemeier, and Smith, 1972; Glynn, ms in preparation; MacIntyre and Smith, 1974; Buddemeier, Margos, and Knutson, 1974; Emiliani and others, 1978; Hudson and others, 1976; MacIntyre, ms in preparation).

The coral core from Glover Reef $\left(16^{\circ} 50^{\prime} \mathrm{N}, 87^{\circ} 50^{\prime} \mathrm{W}\right)$ is located in the Gulf of Honduras approximately $40 \mathrm{~km}$ east of Belize (formerly British Honduras) (fig 1). Glover Reef is an oval-shaped reef, surrounded on its east and west sides by deep, fast moving ocean water. In some ways this location is even more ideal than the Florida site, because there is no bay water influx to the reef and the coral is sufficiently away from the coast to allow for total flushing of the reef with open ocean waters. Surface waters in the Gulf of Honduras are supplied by southeasterly Caribbean currents, which are part of the Gulf Stream system (Wüst, 1964; Climatological and Oceanographic Atlas for Mariners, 1959).

The Belize coral core was collected from 5m depth in July 1977 and represented $1.2 \mathrm{~m}$ of vertical growth. The coral species, Montastrea annularis, displayed continuous annual bands from AD 1868 to 1977. Each section of the core was slabbed in the direction of corallite growth and X-rayed (Hudson and others, 1976). High density bands formed during the warm months of July through September, and less dense bands formed during the cooler months of October through June (Hudson, personal communication). Coral samples younger than 1955 were of single years, whereas older samples consisted of three consecutive years of coral growth.

The Florida core was collected from The Rocks reef at $4 \mathrm{~m}$ depth. The reef was constantly flushed with surface waters from the Florida Straits. Other details were described by Druffel and Linick (1978).

\section{Measurement procedures}

Each coral growth ring or group of rings was converted to acetylene gas via lithium carbide. Four gas proportional beta-counters were employed to measure ${ }^{14} \mathrm{C}$ activity. Each sample was counted for two consecutive days in each of two counters. Two quartz counters, with volumes of 2.4 and 2.8 liters, were used to measure most samples. Two stainless steel counters, with volumes of one liter and $400 \mathrm{~cm}^{3}$, were used for small samples.

All results published here are reported as $\Delta^{14} \mathrm{C}$ in per mil $(\% c)$ (Broecker and Olson, 1961). The standard used is 0.95 NBS oxalic acid whose $\delta^{13} \mathrm{C}$ is corrected to $-19.0 \%$ (PDB). All $\Delta^{14} \mathrm{C}$ values are normalized to a $\delta^{13} \mathrm{C}$ of $-25.0 \%$ and for ${ }^{14} \mathrm{C}$ decay from the time of ring formation to $\mathrm{AD} 1950$.

\section{Pre-anthropogenic $\Delta^{14} C$ values}

Nineteenth century, pre-anthropogenic $\Delta^{14} \mathrm{C}$ values for the Belize coral averaged about $-49 \pm 3 \%$ (fig 2). Those values for the Florida coral 
averaged $-51 \pm 2 \%$. The base-line for the two areas in the Gulf Stream are essentially the same. The reasons for the 5 percent depletion in surface ocean waters with respect to the atmosphere are assumed to be diffusion of older, deeper waters to the surface and the low rate of exchange of $\mathrm{CO}_{2}$ between the atmosphere and surface ocean waters.

\section{Fossil fuel $\mathrm{CO}_{2}$}

The combustion of fossil fuels since the late 1800 's is the cause of the 11 to 15 percent rise in the $\mathrm{CO}_{2}$ content of the atmosphere (Keeling, 1973). It is assumed that the oceans have taken up about half of the industrial $\mathrm{CO}_{2}$ produced. As this excess $\mathrm{CO}_{2}$ contains no measurable ${ }^{14} \mathrm{C}$, atmospheric $\Delta^{14} \mathrm{C}$ levels observed in tree rings exhibit a decline of about 20 to $30 \%$ by 1955 in the northern hemisphere (Revelle and Suess, 1957; Münnich and Vogel, 1958; Brannon and others, 1957; Houtermans, Suess, and Munk, 1967; Stuiver, personal communication). An exponential curve fitted through the Belize $\Delta^{14} \mathrm{C}$ values from 1900 to 1955 is shown in figure 2. This type of fit is used because the input of fossil fuel $\mathrm{CO}_{2}$ to the atmosphere has increased nearly exponentially since about 1900 . The decrease is about $13 \%$ by 1955 . Extrapolation of this curve reveals an additional

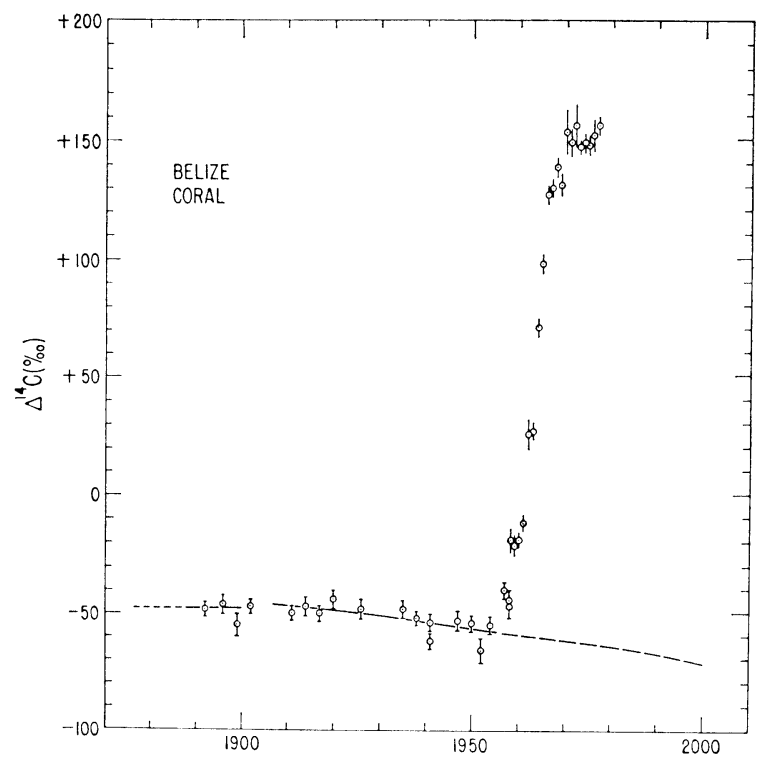

DATE OF FORMATION (YEARS A.D.)

Fig 2. $\Delta^{14} \mathrm{C}$ for samples from the Montastrea annularis coral core from Glover Reef. Coral samples younger than 1955 were of single years, and older samples consisted of three consecutive years. Error bars represent two-sigma counting errors. The solid line from 1885 to 1900 represents the average $\Delta^{14} \mathrm{C}$ of the coral (thus for surface ocean waters of the Gulf Stream) in the late 1800's and early 1900's, viz $-49 \pm 3 \%$. The solid line through points from 1900 to 1956 represents an exponential curve fitted through the experimental $\Delta^{14} \mathrm{C}$ values for the time during which fossil fuel $\mathrm{CO}_{2}$ was present in the atmosphere. The dashed line is an extrapolation of this exponential curve indicating future uptake of fossil fuel $\mathrm{CO}_{2}$, which predicts an additional decline of $\Delta^{14} \mathrm{C}$ of $13 \%$. 
decrease of $13 \%$ predicted by the year AD 2000. In comparison, the Florida coral core revealed an $11 \%$ decline in $\Delta^{14} \mathrm{C}$, from $-51 \%$ in 1900 to $-62 \%$ o by 1955 .

\section{Bomb-produced ${ }^{14} \mathrm{C}$}

Due to the production of ${ }^{14} \mathrm{C}$ by thermonuclear bombs from 1957 to $1963,{ }^{14} \mathrm{C}$ concentrations in the northern hemisphere increased by a factor of two above normal. Figure 4 illustrates the decrease of atmospheric ${ }^{14} \mathrm{C}$ levels after 1965, primarily due to isotopic exchange of $\mathrm{CO}_{2}$ with the oceans. The Belize coral data illustrates the uptake of this bomb ${ }^{14} \mathrm{C}$ from the year 1957 to 1977 (fig 3). A maximum of $151 \pm 4 \%$ was reached by 1970. The Florida core reached a maximum of $153 \pm 5 \%$ by about 1970 (fig 3). Both sets of data agree remarkably well during this period. The reason for the time lag between the $\Delta^{14} \mathrm{C}$ maxima for the atmosphere and surface ocean is due to the slow rate of exchange for $\mathrm{CO}_{2}$ between the two reservoirs. Similar $\Delta^{14} \mathrm{C}$ values for DIOC in the surface waters of the North Atlantic were obtained by Geosecs in 1972-73, which averaged about 150 to $180 \%$ (Östlund, Dorsey, and Rooth, 1974; Östlund, Dorsey, and Brescher, 1976). Similar values were obtained for the northern midPacific (fig 4), averaging 160\% by 1970 (Linick, 1975).

\section{DISCUSSION}

A comparison of the $\Delta^{14} \mathrm{C}$ values obtained for Belize and Florida coral reveals nearly total agreement of all aspects of these data. The preanthropogenic level for the 19th century is $-50 \pm 2 \%$ for surface waters of the Gulf Stream. This value may change slightly once the remaining samples from the Belize core are measured. The important point, however, is that the base-lines are nearly the same for both areas.

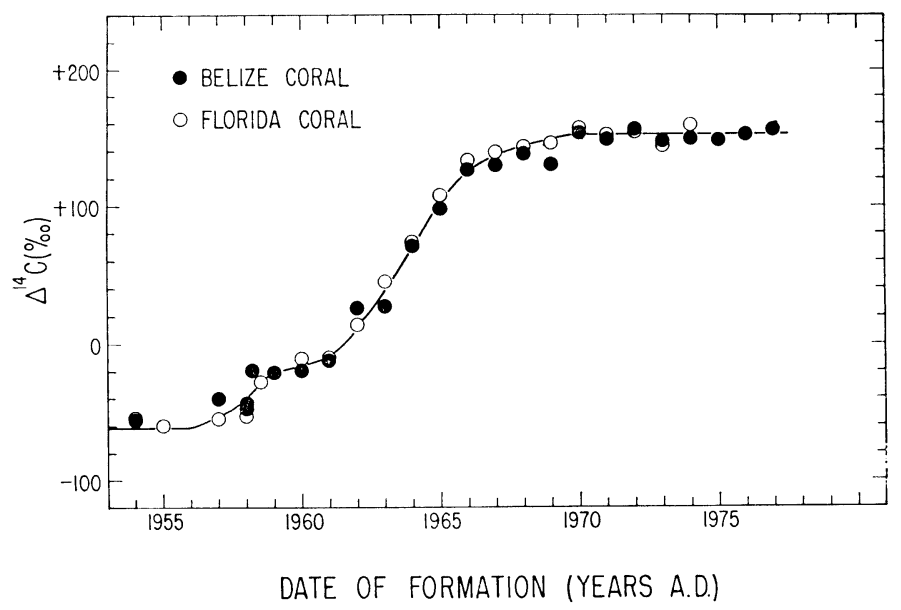

Fig 3. Post bomb $\Delta^{14} \mathrm{C}$ values for Montastrea annularis coral from The Rocks in the Florida Straits and Glover Reef, Belize. Both sets of data are remarkably similar, because the source water to both reefs is the Florida Current (Gulf Stream). These data also agree with $\Delta^{14} \mathrm{C}$ values from Geosecs for the North Atlantic, which average 150 to $180 \%$ during 1972-73 (Östlund, Dorsey, and Rooth, 1974; Östlund, Dorsey, and Brescher, 1976). 
The uptake of industrially-produced $\mathrm{CO}_{2}$ by the surface waters of the Gulf Stream has resulted in a $12 \%$ decrease in $\Delta^{14} \mathrm{C}$. This value represents the average for those seen in both Belize and Florida coral. Likewise, an average of the plateaus observed for bomb-produced ${ }^{14} \mathrm{C}$ reveal a $214 \%$ o increase in $\Delta^{14} \mathrm{C}$ for the Gulf Stream surface waters.

The origin of Gulf Stream waters, which supply the Gulf of Honduras and the Florida Straits, is mainly the southwestern Sargasso Sea and the North Equatorial Current (Iselin, 1936; Stommel, 1965). Less than onethird of the water originates from the South Atlantic. Recent studies have indicated that the exchange rate of $\mathrm{CO}_{2}$ between the air and temperate surface waters varies minimally with latitude. Therefore, since the $\Delta^{14} \mathrm{C}$ records for Florida and Belize coral are virtually identical, we can conclude that vertical mixing for both of these areas in the Florida Current (Gulf Stream) are essentially the same. Furthermore, any differences in vertical mixing that may exist are certainly dwarfed by the rapid horizontal movement of the Florida Current. The agreement between Geosecs data and the coral data for the post-bomb era further illus-

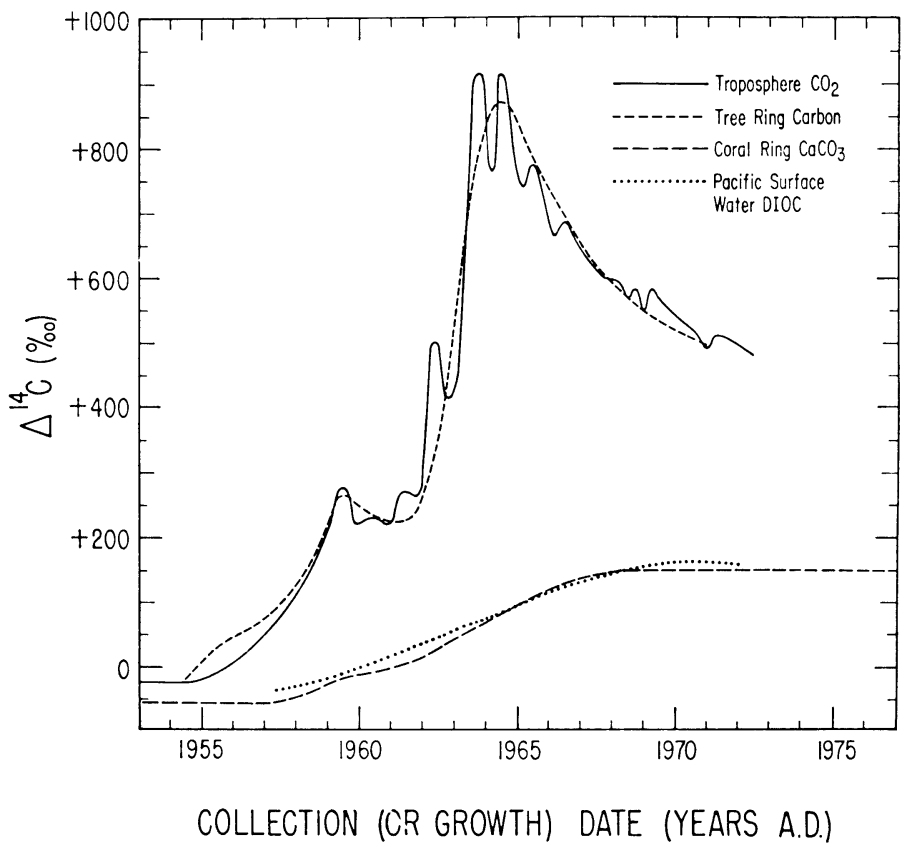

Fig 4. $\Delta^{14} \mathrm{C}$ trends for troposphere, surface oceans, and land biota during the period affected by bomb ${ }^{14} \mathrm{C}$. 1) $\Delta^{14} \mathrm{C}$ measurements of various authors for tropospheric carbon dioxide. Monthly averages for numerous stations in the northern hemisphere were used to obtain a smoothed curve (after Linick, 1975); 2) $\Delta^{14} \mathrm{C}$ measurements by Cain and Suess (1976) for annual tree rings of a Bear Mountain Oak from rural New York State; 3) Average $\Delta^{14} \mathrm{C}$ for annual Montastrea annularis coral rings from the Florida Straits and Glover Reef, Belize; 4) $\Delta^{14} \mathrm{C}$ values of dissolved inorganic carbon (DIOC) in the surface waters of the North Pacific gyre (Linick, 1975). Radiocarbon measurements were averaged for a latitude range of $15^{\circ} \mathrm{N}$ to $27^{\circ} \mathrm{N}$, and a longitude range of $140^{\circ} \mathrm{E}$ to $120^{\circ} \mathrm{W}$. 
trates that we are, in fact, measuring ${ }^{14} \mathrm{C}$ levels that existed for past Gulf Stream surface waters.

These data in no way illustrate, however, the average $\Delta^{14} \mathrm{C}$ records of fossil fuel $\mathrm{CO}_{2}$ and bomb ${ }^{14} \mathrm{C}$ in the world's surface oceans. Preliminary $\Delta^{14} \mathrm{C}$ results from coral of the eastern equatorial Pacific illustrate lower values for pre-bomb years (by about $15 \%$ ) and bomb ${ }^{14} \mathrm{C}$ concentrations of about half that observed for the Florida Current by 1970 (Druffel, ms in preparation). This is due to upwelling along the equator, which is especially enhanced along eastern boundaries.

In conclusion, hermatypic coral skeletons living in suitable areas provide permanent annual records of past radiocarbon concentrations of DIOC in surface ocean waters. This is a useful method for recovering data we thought were lost due to the penetration of bomb ${ }^{14} \mathrm{C}$ into the oceans. If coral from enough areas are studied in this manner, we can obtain a better estimate of the amount of fossil fuel $\mathrm{CO}_{2}$ taken up by the oceans. Also, estimates of equatorial upwelling rates can be improved using these data.

\section{ACKNOWLEDGMENTS}

Thanks go to members of the USGS, Miami Beach, especially J H Hudson and E A Shinn, for so kindly providing both coral cores described in this publication. I thank T Linick for his technical skills, and both him and $\mathrm{R}$ Michel for their professional advice. I thank S Griffin and C Hutto for their superior technical services. I especially thank Hans E Suess for his keen insights into this problem. I gratefully acknowledge the National Science Foundation for support through Grant No. EAR78-15183 with Hans Suess as Principal Investigator.

\section{REFERENCES}

Bien, G S, Rakestraw, N W, and Suess, H E, 1960, Radiocarbon concentration in Pacific Ocean water: Tellus, v 12, p 436-443.

Brannon, H R, Jr, Daughtry, A C, Perry, D, Whitaker, W W, and Williams, M, 1957, Radiocarbon evidence on the dilution of atmospheric and oceanic carbon by carbon from fossil fuels: Am Geophys Union Trans, v 38, p 643-650.

Broecker, W S, Gerard, R, Ewing, M, and Heezen, B C, 1960, Natural radiocarbon in the Atlantic Ocean: Jour Geophys Research, v 65, p 2903-2931.

Broecker, W S and Olson, E A, 1961, Lamont radiocarbon measurements VIII: Radiocarbon, v 3, p 176-204.

Broecker, W S, Peng, T H, and Stuiver, Minze, 1978, An estimate of the upwelling rate in the equatorial Atlantic based on the distribution of bomb radiocarbon: Jour Geophys Research, v 83, p 6179-6186.

Buddemeier, R W, Margos, J E, and Knutson, D W, 1974, Radiographic studies of reef coral exoskeletons: Rates and patterns of coral growth: Jour Exp Marine Biol Ecol, v 14, p 179-200.

Cain, W F and Suess, H E, 1976, ${ }^{14} \mathrm{C}$ in tree rings: Jour Geophys Research, v 81, p 3688-3694.

Climatological and Oceanographic Atlas for Mariners, 1959, v 1, North Atlantic Ocean, US Office Climatology Div Oceanog, Washington, DC: US Govt Printing Office, charts 117-128.

Druffel, E M and Linick, T W, 1978, Radiocarbon in annual coral rings of Florida: Geophys Research Letters, v 5, p 913-916.

Emiliani, C, Hudson, J H, Lidz, B, Shinn, E A, and George, R Y, 1978, Oxygen and carbon isotopic record of growth in reef coral from the Florida Keys and a deepsea coral from Blake Plateau: Science, v 202, p 627-629. 
Houtermans, J, Suess, H E, and Munk, W, 1967, Effect of industrial fuel combustion on the carbon-14 level of atmospheric $\mathrm{CO}_{2}$ : Radioactive dating and methods of lowlevel counting, Proc, Austria, IAEA, p 57-68.

Hudson, J H, Shinn, E A, Halley R B, and Lidz, B, 1976, Sclerochronology: A tool for interpreting past environments: Geology, v 4, p 361-364.

Iselin, C O D, 1936, A study of the circulation of the western North Atlantic: Papers Phys Oceanog Meteorol, v 4, 100 p.

Keeling, C D, 1973, Industrial production of carbon dioxide from fossil fuels and limestone: Tellus, v 25, p 174-198.

Knutson, D W, Buddemeier, R W, and Smith, S V, 1972, Coral chronometers: seasonal growth bands in reef corals: Science, v 177, p 270-272.

Linick, T W, 1975, Uptake of bomb-produced radiocarbon in the surface water of the Pacific Ocean: PhD dissert, Univ California, San Diego, 255 p.

v 20, p 333-359.

MacIntyre, I G and Smith, S V, 1974, X-radiographic studies of skeletal development in coral colonies, in Cameron, A M, ed, Internatl Symposium Coral Reef, 2nd, Proc, v 2: Queensland, Australia, Courier-Mail Printing Service, p 277-287.

Münnich, K O and Vogel, J C, 1958, Durch Atomexplosionen erzeugter radiokohlenstoff in der atmosphare: Naturwissenschaften, v 14, p 327-329.

Östlund, H G, Dorsey, H G, and Brescher, 1976, Geosecs Atlantic radiocarbon and tritium results: Tritium lab data rept no. 5, Univ Miami, Rosensteil School Marine Atmospheric Sci, 94 p.

Östlund, H G, Dorsey, H G, and Rooth, C G, 1974, Geosecs North Atlantic radiocarbon and tritium results: Earth Planetary Sci Letters, v 23, p 69-86.

Rafter, T A, 1968, Carbon-14 measurements in the South Pacific and Antarctic Oceans: New Zealand Jour Sci, v 11, p 551-589.

Revelle, $\mathrm{R}$ and Suess, H E, 1957, Carbon dioxide exchange between atmosphere and ocean and the question of an increase of atmos $\mathrm{CO}_{2}$ during the past decades: Tellus,
$v 9$, $18-27$.

Stommel, H, 1965, The Gulf Stream: Berkeley and Los Angeles, Univ California Press, p 33.

Weber, $\mathrm{J} \mathrm{N}, 1974,{ }^{13} \mathrm{C} /{ }^{12} \mathrm{C}$ radios as natural isotopic tracers elucidating calcification processes in reef-building and non-reef-building corals, in Cameron, $\mathrm{A} \mathrm{N}$, ed, Internatl Symposium Coral Reefs, 2nd, Proc, v 2: Queensland, Australia, Courier-Mail Printing Service, p 289-298.

Williams, P M and Linick, T W, 1975, Cycling of organic carbon in the ocean: Use of naturally occurring radiocarbon as a long and short term tracer: Isotope ratios as pollutant source and behavior indicators, Vienna, IAEA, p 153-167.

Wüst, G, 1964, Stratification and Circulation of the Antillean-Caribbean Basins, Part 1: New York, Columbia Univ Press, p 66-69.

\section{DISCUSSION}

Roether: I wonder whether it would be possible to obtain similar ${ }^{14} \mathrm{C}$ records for higher latitudes. Such would be of particular interest in the northern North Atlantic, where much of the deep water of the world ocean has its source but for which very little pre-bomb ${ }^{14} \mathrm{C}$ data exists.

Druffel: Unfortunately, hermatypic coral growth is extremely strained when subjected to temperatures below $19^{\circ}-20^{\circ} \mathrm{C}$. Thus, coral growth is limited to latitudes between about $35^{\circ} \mathrm{N}$ and $32^{\circ} \mathrm{S}$. In contrast, ahermatypic corals are not limited by temperature or ambient light, but they incorporate far less inorganic carbon from the sea water to their skeletons. These would be useful for the purposes you mentioned if the carbon source to the skeleton is similar in $\Delta^{14} \mathrm{C}$ to that of DIOC (dissolved inorganic carbon) from the sea water. Also, the banding in these corals shows far less accretion of aragonite. The nature of the banding in ahermatypic corals is not clearly established.

Gove: How far back in time do coral samples go? 
Druffel: I presume you are interested in recent coral growth whose annual bands are of known age. The coral core from the Florida Straits mentioned today extends back to about AD 1650. This is the oldest core I know of. I expect that there are continuous growth records older than this for areas with relatively stable weather conditions and equally as favorable conditions for coral growth as those in Florida (ie, water temperature between $22^{\circ}$ and $28^{\circ} \mathrm{C}$, low turbidity, standard ocean salinities, plentiful sunlight, etc). It takes only one bad storm kicking up sediment or one cold spell with enough duration to kill a coral head. A good overview of coral growth was written by R W Buddemeier, 1974, cited in my references. 